\title{
Vandalism problem in tourism and solution proposals: The case of Neuşehir
}

\author{
İbrahim Yılmaz, Gülsüm Tabak*, Arif Nihat Samur
}

\section{ABSTRACT}

Keywords:

Tourism,

Vandalism,

Nevşehir.

\section{Article History:}

Submitted:19.03.2019

Accepted: 24.08 .2020
The aim of this study is to examine the phenomenon of vandalism with in the scope of tourism, to reveal the vandal event soccurring in Nevşehir Province with pictures and interview sand to develop solutions for its prevention. Within the scope of the study, literature review conducted by the researcher and then the damages caused by vandalism to the environment were tried to reveal by the help of the photographs taken in certain parts of Nevsehir. In the study, primary data were obtained from the interview with three district mayors and two non-governmental organizations (NGO) representatives. In the analysis of the collected data, descriptive analysis method, which is one of the qualitative research analysis techniques, was preferred. According to the primary and secondary data obtained, it was concluded that vandalism incidents were wide spread in Nevşehir province and that these behaviors caused serious damage to natural and historical artifacts. Another noteworthy result is that there are problems in taking the necessary measures due to the confusion of authority stemming from the presence of more than one institution in decision-making position.

\section{Introduction}

Vandalism is one of the problems faced in almost every aspect of life. Some of the common vandalism behaviors are writing on walls, damaging the works in museums, engraving names in public areas, breaking windows of buildings, using signs and traffic lights as targets and taking pieces from historical works. Vandalism, which is considered as a negative behavior in all aspects, prevents the reuse of materials and causes a financial loss by repairing the damage done. It is very important to examine these behaviors and identify the damages not only in public areas, but also for the tourism phenomenon that uses the natural environment as a resource. Vandalism is basically "illegal destruction of goods belonging to someone else or deliberate deterioration of their appearance" (Yener et al., 2004:145).

Historical and natural buildings are among the most important sources of a country's tourism capital (GunnandVar, 2002: 62-63). Because the cultural richness of an area contributes greatly to the tourism potential of that country and protects the future of tourism for that region (Patin, 1999: 35).Nevşehir province, which has a natural structure, is an important destination in terms of its geographical location and historical richness, but with the damage to historical and cultural structures, they are in danger of extinction (Tutar et al., 2007: 203). Due to the increasing number of people coming to Nevşehir every year, the absence of valid sanctions and laws, the lack of statistical information and insufficient protective measures of natural structures, historical sites and cultural structures are worn day by day.

The main subject of this study is the measures to be taken to reveal and protect the damage given to the historical and natural structures that are the basis of tourism. In line with this purpose, the history and the concept of vandalism was primarily examined. Then, the areas where vandalism is frequently seen and the studies conducted in this

\footnotetext{
*Corresponding Author

İbrahim Yulmaz: Prof. Dr., Nevşehir HacıBektaşVeli University, Faculty of Tourism, Department of Tourism Guidance, Turkey, Email:iyilmaz@nevsehir.edu.tr,Orcid Id: https://orcid.org/0000-0003-1493-5379

Gülsüm Tabak: Lecturer, Isparta University of Applied Science, Eğirdir Vocational School, Department of Tourism Management Turkey, Email:gulsumtabak@isparta.edu.tr, Orcid Id: https://orcid.org/0000-0001-8735-348X

ArifNihatSamur: Lecturer, Nevşehir HacıBektaşVeli University, Kozaklı Vocational School, Department of Tourism Management, Turkey, Email: asamur@nevsehir.edu.tr, Orcid Id: https://orcid.org/0000-0001-8081-5231
} 
area are examined and examples of vandalism occurred in the world and in Turkey are menioned. In addition, vandalism events in the Nevşehir region were photographed, and deeper information was obtained by discussing with people on this issue.

\section{Vandalism}

Vandals, an East German race, are known for their damage and looting to the environment during the wars with the Roman empire, which established a kingdom in Africa in the early years of the AD. The vandals, who fled to the West in the first periods of the 5 th century, invaded a certain part of Gaul and settled in Spain. The "Asding Vandals" led by King Gunderich gradually became the dominant group, and later gained allied status in 435 by signing an agreement with Rome. In the following period, they ended their dependency on Rome and became independent and in this process they confiscated all the agricultural areas that belonged to the Romans (Tarakçı, 2013:7). Because of all these realities, the concept of vandalism is a term used to refer to a tribe, to express the tendency of someone to behave aggressively towards the public or private property of people they do not know (DiCanio, 1993:55)

Vandalism, which is associated with fields such as sociology, psychology, criminology, architecture, has been described in different ways by researchers from different disciplines. According to Conklin (1989: 110), vandalism is "the destruction, damage, degradation of shape or appearance of a property without the permission of its owner". Vandalism is the behavior of damaging structures, official institutional goods, and others' belongings for various reasons or for pleasure (Boz and Beyaztaş, 2001: 17).In other words, vandalism is the act of deliberate and malicious harm to any private or public property (Fisherand Baron, 1982; Moser, 1992; Olgun and Yllmaz, 2015: 28; Erkan, 2005). According to Namba and Dustin (1992), vandalism is deliberate behavior that reduces the economic or aesthetic value of an object or area. Indeed, people who exhibit vandal behavior do it voluntarily and they are aware that they damage the private or public property of people they do not know (Yener et al., 2004:145).

Vandalism can appear in almost every part of our daily life. It is frequently seen especially in parks, educational areas, public transportation vehicles, official institutions and organizations, streets, and in historical and touristic areas (Van Vliet, 1984: 14). If investigated why people with vandal behavior exhibit such behavior, many different reasons are encountered. Some researchers explained the causes of vandalism with various cases of poverty, while others argued that they may be related to the shape, size and type of the workd in the environment. The reasons of the vandalism should not be approached from a single point of view. Perhaps the most important of the underlying causes of these type of behaviors are psychological and emotional factors. People can take vandalist actions as a result of situations such as dissatisfaction, a sense of failure, boredom, and bad relationships (Türkoğlu, 1991).

It is seen that studies on vandalism are mostly addressed in foreign literature (DeMore et al., 1988; Mayer et al., 1983; Gladstone, Sturman and Wilson, 1978; Allen and Greenberger, 1978; Duneier and Molotch, 1999; Bhati and Pearce, 2016). One can see that the subject of vandalism in Turkey has been studied in areas like education (Orhan, 2015; Oruç, 2008; Doğanand Demir, 2012; Tarcan, 2007; Ünişen and Demirbağ, 2016; Yıldırım, 2017), public spaces (Tarakçı, 2003; Çevik Aladağ, 2011) and public goods (Akyol, 2006; Doğan, 2007). However, vandalism studies evaluated in the phenomenon of tourism are not sufficient. A few studies addressed in the context of tourism are listed below.

The research by Avcl, Acar and Aslitürk (2016) examined the cultural assets in Selcuk, Izmir and Kusadasi, Aydin within the framework of vandalism. According to the results obtained, it is observed that the destructions on the cultural assets in those regions are quite high.

Bhati and Pearce (2016) investigated the concept of vandalism and why vandalism emerged in tourism, the relationship between vandalism and motivation, opportunity and intent. According to the findings, various strategies have been developed to intervene in such behaviors in tourism areas.

In the research conducted by Güleken and Ünal (2018), the relationship between location and environment was examined in the historical development process of Kendirli Church and Latin School, protection interventions were developed and suggestions were presented by evaluating the damages that occurred over time in the context of their occurrence. At the end of this study, it was seen that inscriptions were written on the walls of the bell tower of the historical building, the stalactides were removed, and the floor was destroyed for treasure search. 


\section{Effects of Vandalist Actions on Tourism and Examples from the World and Turkey}

Writing, drawing, painting, and scratching on the works that have historical and cultural values are common in other countries and in our country. This section of the study gives examples from selected occured events in the world's and Turkey's various regions and are supported by several news.

\section{Coloseum (Italy)}

Located in Italy, Coloseum is an important historical and cultural tourist area. Coloseum, which hosts thousands of visitors every year, is one of the places where vandalism is common. One of the columns of the Coloseum was written a $25 \mathrm{~cm}^{-}$ wide letter "K" by a Russian tourist in the past years and this person was fined $20.000 €$. on April 28, 2019, a Bulgarian student engraved the letter "M", the beginning of his name, on the interior wall of the Coloseum amphitheater. In addition, two Brazilian tourists were injured while trying to enter the Coloseum in the nighttime in 2017. Although Graffiti is the biggest problem for the Colosseum, there are many visitors who try to steal the bricks and other parts of the building as souvenirs (www.thelocal.it).

\section{National World War I Museum (Kansas/USA)}

The vandals also damaged the liberty memorial in the US, the state of Kansas. Vandals wrote "Glory to the fallen martyrs" in different places to draw attention to the Peruvian Prison Massacre that occurred in 1986 (https://fox4kc.com).

\section{Norman Firehouse Art Center (Oklahoma /USA)}

The sculptures at the Oklahoma Firehouse Art Center in Oklahoma have been exposed to racist vandalism actions. Seeing same shapes and colors in "McKinley Primary School" and at the headquarters of "Cleveland County Democratic Party" suggest that the same group did these actions (www.tulsaworld.com).

\section{St. Francis Church (Vineland/New Jersey)}

The sculptures in St. Francis Church in New Jersey have been damaged in various ways. When the painting is carefully examined, it is seen that especially faces and eyes of the sculptures representing the Prophet Jesus, the Virgin Mary and the Prophet Joseph were deliberately broken (https://philadelphia.cbslocal.com).

\section{Urartu Inscriptions (Van /Turkey)}

Since Van and its surroundings are from important Urartu settlement areas, inscriptions from those periods are very common. Two of the inscriptions engraved with cuneiform writings are on the VanErcis highway and the other one is in the neighborhood of Salmanaga and Celebibag1 (www.ercis.gov.tr). 2750 years old inscriptions are located in a place where many people can easily reach. It is thought that people who destroyed the inscriptions with spray paint probably wrote their initials on them. Lack of warning signs around the inscriptions indicates that the works are not protected well (www.turizmhaberleri.com).

\section{Sumela Monastery (Trabzon/Turkey)}

The Sümela Monastery in Trabzon is one of the most important cultural heritages of the world. In this monastery, centuries-old frescoes have become invisible due to vandalism. In the picture below, it was revealed that these frescoes were damaged even in the 1400 s and there were inscriptions in many languages including Turkish, Hebrew, Latin and Arabic (www.haberts.com).

\section{Method}

The main objective of the research is to determine the vandal incidents in Nevsehir province with pictures and interviews and to develop recommendations for preventing damage to natural and historical sites. It is thought that more detailed information and data can be accessed through qualitative research methods. Qualitative research can be defined as a research method that involves information gathering processes such as observation, interview and document analysis that examine perceptions and events in their natural environment and reveal them in a real way in a very precise state (Ylldırım, 1999:9-10).In the research, document review and semi-structured interview techniques, which are qualitative research methods, were used. In the interview technique often used in qualitative research, the researcher has a very important role because he/she wants to systematically reveal the person's thoughts and feelings in the guidance of the questions he / she has prepared in advance about the subject he / she is investigating, or by directing questions at the moment of interview. In short, the researcher attempts to uncover and learn the way people think, perceive, feel and comment through systematic questions (Kvale, 1996: 5).

In the analysis of the collected data, descriptive analysis method, which is one of the qualitative research analysis techniques, was preferred. Descriptive analysis can be defined as a technique wherethe information obtained is summarized and interpreted according to the previously determined topics, direct quotations are used to reflect the views of the interviewees in a good way and interpretation of the collected data are done within the framework of cause-effect relations (Yıldırım 


\section{lomat}

and Şimşek, 2008). In order to ensure the validity and reliability of the research, the interview form was given to three field experts and the final form was established accordingly. After a meeting with a mayor other than the participants, the voices recorded during the interview were converted into written form created on a computer environment in order to determine whether the questions were clear and understandable and whether the answers reflected the answers to the questions asked. Another expert was asked to check whether the questions asked are clear and cover the subject being addressed and whether they provide the necessary information. In addition, the data obtained were examined by two different researchers at different times and the results were compared. In this context, it can be stated that this research provides criteria for validity and reliability. The universe of the research consists of people in Nevsehir province who are thought to have the authority to make decisions about vandalism. The research sample was chosen using the criterion sampling method, which is one of the purposeful sampling methods. Purposeful sampling allows for in-depth analysis of situations that are considered to have rich knowledge (Patton, 2002).

\section{Findings and Discussion}

Nevşehir region has always been one of the most important regions of Turkish tourism with its natural beauties. Unfortunately, these beauties have become the target of vandal attacks from past to present, as can be seen in the pictures given below. These vandal attacks sometimes continued with the behaviors brought by uneducatedness and sometimes due to commercial concerns.

Especially the face and eyes of the wall paintings of churches dating back centuries were engraved with pointed tools and destroyed by throwing stones. Some churches have been used for warehouses, pigeon houses, and other different needs. Due to the arbitrary fire in the church and similar places, dense soot layers have formed on the surfaces. This has caused great damage to the spatial integrity and originality of churches. Although they are within the protected area and, especially for commercial purposes, the hotel constructions, shops selling tourist souvenirs, restaurants and café-style establishments have increased that damage the fairy chimneys and similar natural formations. Unfortunately, this process becomes a legal process with the development plan law decisions that are issued at certain periods.

\section{İbrahim Yılmaz, Gülsüm Tabak, Arif Nihat Samur}

As it can be seen in the picture1,2,3 facilities have been built for commercial purposes next to, among, and adjacent to natural and cultural values. In the pictures $4,5,6$, the damage caused by human beings to the hundreds of years old churches is seen.

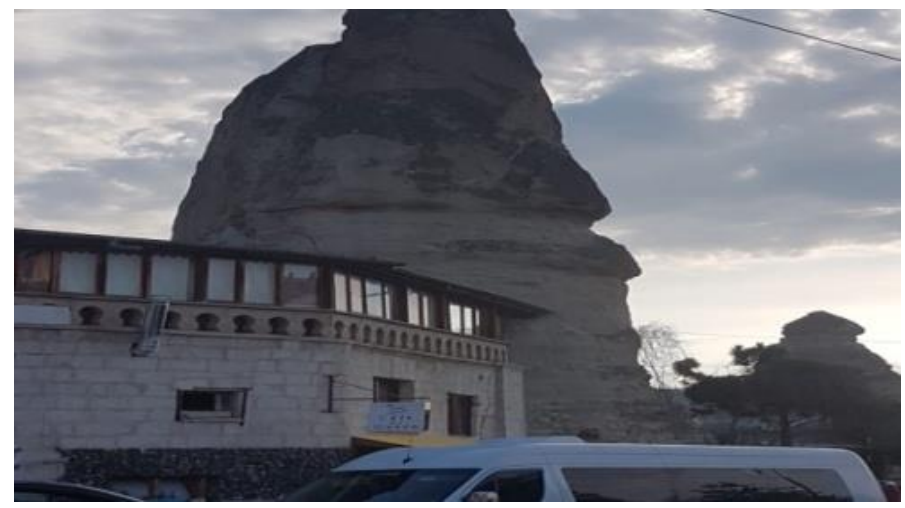

Figure 1

Source: Authors

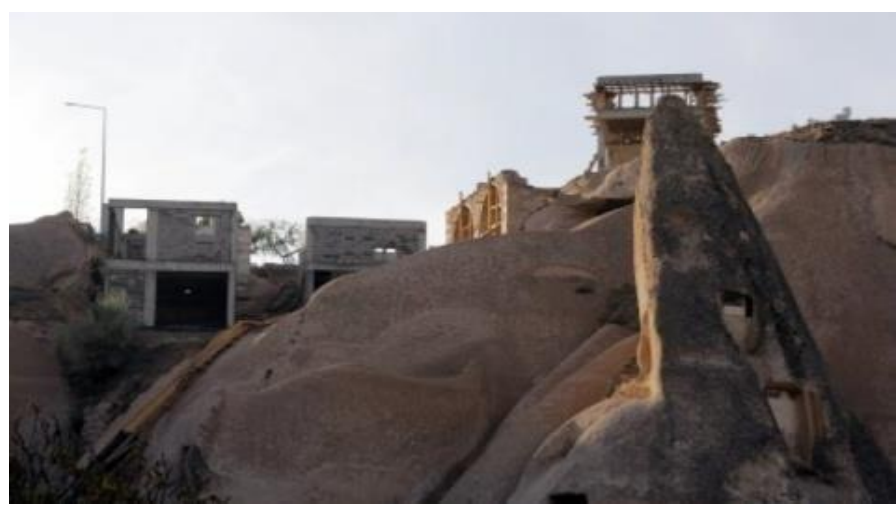

Figure 2

Source: Authors

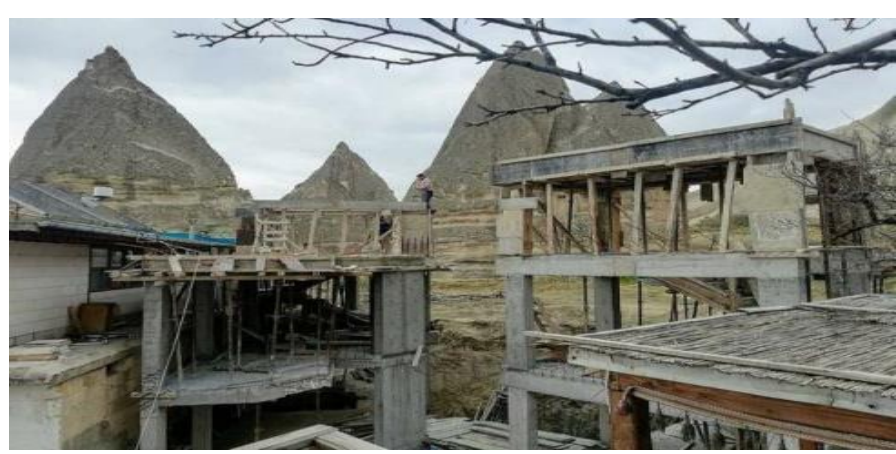

Figure 3

Source: https://www.turkiyeturizm.com/peribacalarina-skandal-otel-insaatinakim-izin-verdi-57733h.htm 


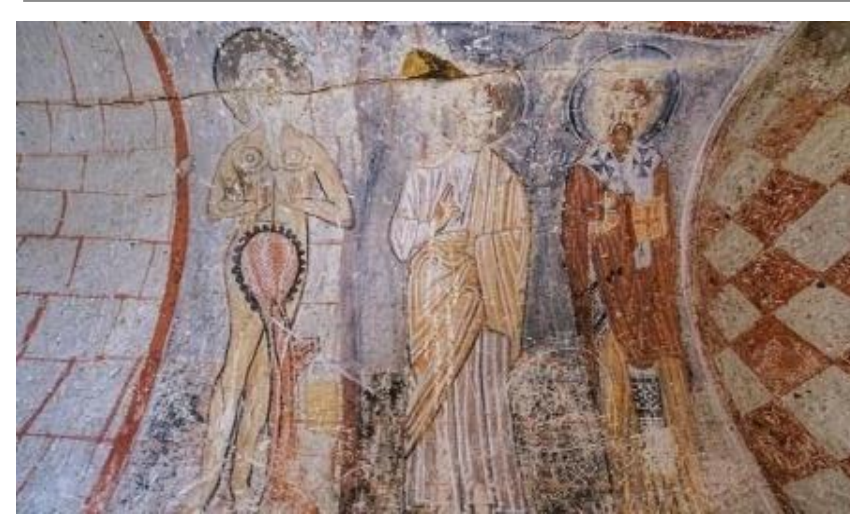

Figure 4

Source: http://www.soniahalliday.com/category-view3.php?pri=TR72-10-11.jpg (Goreme Open Air Museum, Snake Church)

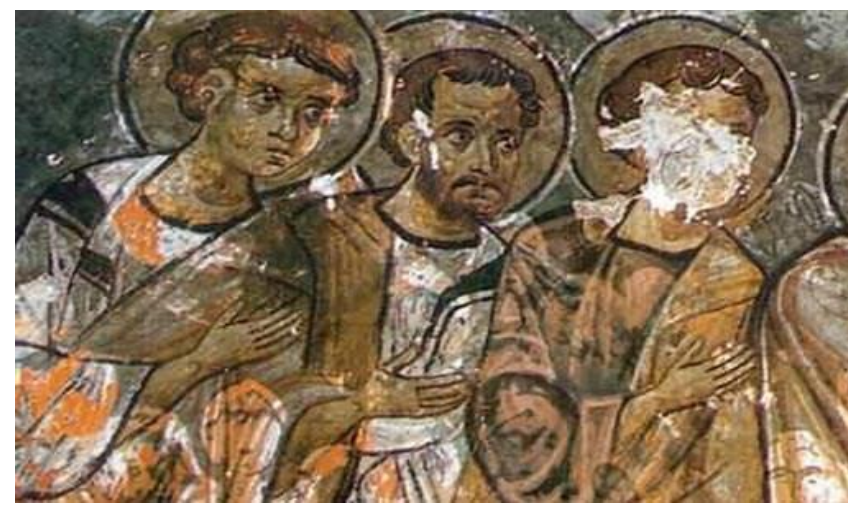

Figure 5

Source: http://www.cappadociaonline.com/soganlitr.html (Soğanlı Valleys)

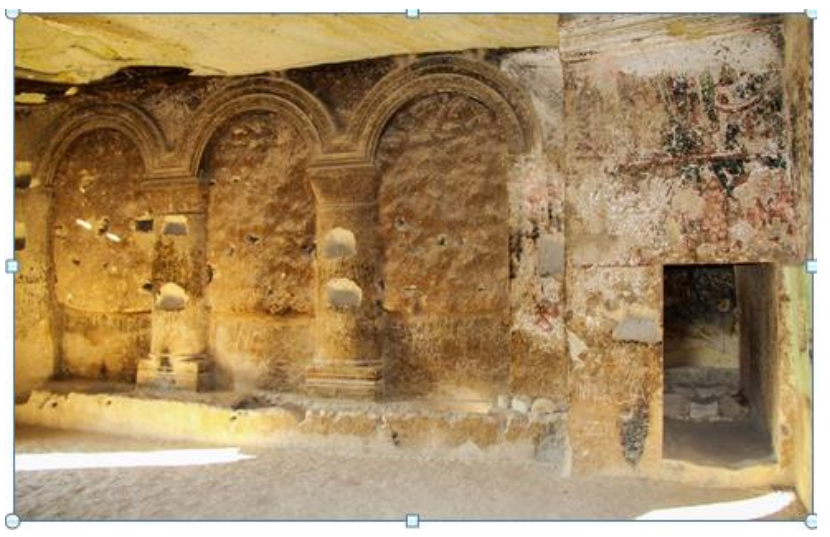

Figure 6

Source: https://th.tripadvisor.com/LocationPhotoDirectLink-g2187725-d3547826i237435407-Church_Of_St_John_The_Baptist_Vaftizci_Yahya_KilisesiCavusin_Cappadoci.html (Church Of St. John The Baptist)

As mentioned earlier, face-to-face meetings were held with three district mayors and two NGO representatives. In this section, the findings obtained from these interviews are analyzed.

\section{Findings Regarding Vandalism Incidents in the Region}

The answers given by the five participants to the first question "What are the vandalism incidents in the region" are summarized below.
"Before tourism was developed in our region, damage was done to the historical areas because these regions were defined as protected areas and generally remained among the lands of the villagers. Those damages have been tried to be minimized recently with legal regulations and protection decisions. Nevertheless, such damages continue to be done in out of sight and not yet declared protected areas. In general, figures in churches are damaged. The natural formations called Fairy Chimneys are harmed either by demolition (to expand the land of cultivation, to open the road) or to use it for commercial purposes (cafeteria, souvenir enterprises and restaurant)." (K1)

"There are destructions from the past in churches and fairy chimneys, which are among the valleys that tourists use extensively within our borders. Some of these damages are those to the pictures. The majority of these are formed by either engraving the pictures completely or writing a certain part of them. In addition, unfortunately, the works carried out secretly by businesses operating as boutique hotels and for other commercial activities have become lawful by develpment plan laws. "(K2)

"The damage given to the works depicting the Christian religion in churches in our region is particularly striking. The fairy chimneys, which are called natural formations, were damaged by being demolished. In addition, damages have been given to the natural formations within the settlements to be used for commercial purposes. "(K3)

"Boutique hotel management activities are carried out intensely within the boundaries of our municipality. Unfortunately there are some problems coming from the past. While these hotels were being built, some natural structures were damaged. In addition, the areas where the graves were found were damaged to search for valuable items." (K4)

"The biggest vandalism seen and experienced in Cappadocia region are jeep and ATV tours. These tours lead to the destruction of fairy chimneys and rocks, which are protected by UNESCO." (K5)

In line with the findings, it was observed that the churches and frescoes were damaged, as well as the natural structures for commercial purposes. It is also among the results that the pictures in churches are engraved or written on. It is understood that the losses have been tried to be minimized by the recent legal regulations and measures, but the effects of those losses from the past still continue. It is believed that jeep and ATV tours also negatively affect the environment.

\section{Findings Regarding Activities to Prevent Vandalism Incidents in the Region}

The answers given by the five participants to the second question "What are the municipalities, nongovernmental organizations or relevant units doing to prevent vandalism in your region? Is there an authorized institution?" addressed to them in the interview are summarized below.

\footnotetext{
"The responsibility of the protected areas belongs to the Ministry of Environment and Urbanization. Official correspondence is made with this institution, but museums are under the control of the Ministry of Culture and Tourism. Since the official bureaucracy works hard, the Area Management Law has been enacted for tourism regions. Although this law is not fully operational, it is certain that it will reduce bureaucracy." (K1)
} 
"We carry out educational activities to increase public awareness about vandalism. But the relevant units of the state are still the main responsible institutions. With the newly established Area management law in our region, field authorities in different units have been collected in one hand." (K2)

"These studies generally remain in theory for commercial concerns. Unfortunately, these damages caused by the development plan law are covered up in order to keep political relations in the foreground." (K3)

"While preparing the zoning plans as municipality, all kinds of legal warnings are made to prevent people from engaging in activities contrary to naturalness. However, this job does not only depend on municipalities." (K4)

"It is the Governor of Nevşehir, which is the hardest opponent of vandalism events. Since other NGOs and official institutions do not have sanction power, they cannot intervene on this issue. As a result of the decision taken by the governorship, a single route for jeeps and similar vehicles was drawn. But no company comply with or respects these routes. " $(K 5)$

In this section, the participants were asked questions about what was done to reduce vandalism events and which authorized institutions were there. According to the findings obtained in this direction, it was observed that there was not a single authorized institution. It has been observed that the institution dealing with the sites and museums are different ones. The view that the bureaucracy takes a lot of time is dominant, but with the "Area Management Law", it is believed to decrease to some extent. In addition, educational activities are organized to prevent such behaviors and to raise public awareness. Also, it is thought that some of the laws enacted damage the natural structure and the consequences of those damages are ignored.

\section{Findings Regarding Cost Studies to Reduce Vandalism} Incidents or Repair Damaged Places

The answers given by the five participants to the third question directed to them in the interview "Is there a cost study to reduce the incidents of vandalism or to repair damaged works?" are summarized below.

\footnotetext{
"Each municipality can make a research for the works that have touristic value within their borders. But there are bureaucratic obstacles. We cannot intervene in damaged buildings as we wish because municipalities do not have a budget for this. "(K1)

"In order to reduce these events, our municipality carries out activities to increase its awareness in the society with advertising, posters and similar tools. However, it is not the municipality's responsibility to repair existing damaged works. Therefore, we do not have a budget for repairing those works." (K2)

"NGOs especially work intensively on this issue, make criminal complaints to the relevant units when such damages are detected and increase social awareness especially by using social media and press." $(K 3)$

"We are working to enlighten our people. However, the municipalities are not authorized to repair damaged works. "(K4)
}

"There are so many fairy chimneys and rock structures that are damaged that it is not possible to perform cost analysis." (K5)

In this section, participants were asked whether they performed any cost analysis to repair the damage. The findings show that the municipalities are not authorized institutions to repair the damage done and that the bureaucracy is an obstacle for them. Municipalities and NGOs have activities to create more positive awareness in this regard.

\section{Findings Regarding Annual Destruction Rate}

The answers given by the five participants to the fourth question directed to them in the interview, "Can you give information about the annual rate of destruction" are summarized below.

\footnotetext{
"It is very difficult to know this, but unfortunately, there are works that are damaged due to construction within our municipal boundaries. "(K1)

"It is very difficult to do a study on this. It is not clear which works were damaged or when. Studies are carried out by municipalities and relevant institutions of the state in order to prevent damage to existing ones." (K2)
}

"It is very difficult to measure this destruction, especially in residential areas. The destruction is so intense that it is not possible to reinstate it." (K3)

"Although it has been decreasing recently, it is very difficult to detect the level of destruction because it is in a wide area." (K4)

"I think the fairy chimneys in the region are damaged by $2 \%$ every year." (K5)

In this section, there are findings regarding the rate of damage to historical and natural structures. The results obtained revealed that no studies were conducted to clarify the annual damage rate because the authorities did not know when and how the work was damaged.

\section{Findings Regarding Studies to Restore the Damaged Places After Vandalism}

The answers given by the five participants to the last question addressed to them in the interview, "What can be done to restore the damaged places after vandalism" are summarized below.

"It is not possible to give a clear answer since we do not allocate a resource for this. However, infrastructure budgets we spend on alternative roads are available especially in the valleys and protected area so that these objects are not damaged." (K1)

"Unfortunately, we do not have a plan on this. We are talking about places under the authority of many different institutions. "(K2)

"The only means of living for the region is tourism. It is not possible to restore the damaged works, and if the damage continues at this rate, culture and natural assets will not be considered as tourism products because the damages are very serious. A substantial cost is required to recover and repair." (K3)

"As a municipality, we do protection activities as much as we can even though we do not have a resource allocated for them. We 
allocate budget for alternative routes and cleaning and maintenance activities in order to prevent further damage to these structures and values." (K4)

"Unfortunately, it is impossible to restore the damaged parts of these structures that God has given to the region." (K5)

The findings about what kind of measures are being taken to repair the damaged works are given in this section. When evaluated on the basis of municipalities, it was seen that their powers were limited but they had some works limited to their borders. It is a common idea that the damage done to touristic products is quite remarkable and it is not possible to regain their naturalness.

\section{Conclusion and Suggestions}

The effects of vandalism, which began attracting attention of people all over the world and affecting many areas negatively, have started to be investigated in all areas. The concept is generally defined as the deliberate destruction of goods belonging to public, private individuals or institutions in various and deliberate ways. Vandalism has become a concept that concerns many disciplines rather than just being a subject that is among the interest of areas such as psychology, sociology, criminology, and architecture. One of those areas is Tourism. Damages to historical sites, churches, sculptures and natural areas, which are the sources of tourism, directly affect it. The damage caused by vandalism to historical and cultural monuments has reached a critical level in the tourism-intensive destinations in our country. Nevşehir is also a location that houses fairy chimneys, historical ruins, important museums and churches. Examples of vandalism in Nevşehir, which causes an increasing number of material and spiritual losses each year, are given in this study within the framework of the tourism sector and inferences were made by taking the opinions of the authorized persons.

The results showed that Vandal behavior is frequently encountered in Nevşehir province, which is an important destination with its historical and natural beauty. These behaviors include scraping the faces of churches and frescoes, and the actions of people writing their own names in the name of leaving a mark of their own. This result is in line with the findings obtained in the study of Açıkgöz and Ahunbay (2008).

In addition, it was seen that fire was burned in churches and old living areas and cemeteries were excavated to search for treasures. In addition, some natural structures are used for different purposes. These results are similar to those found in the study of Eren and Özgüçlü (2005). Another important finding is that Jeep and ATV tours are among the serious threats to the region. Despite the measures taken, it was seen that the tours did not comply with the road routes.

The number of hotels, gift shops, cafes and restaurants in Nevşehir province has also been increasing. It is clearly seen that some of these structures are positioned in a way to damage the natural environment and the fairy chimneys formed by a natural formation. One of the factors that causes this situation is that the legal arrangements made during certain periods under the name of development plan law lay the groundwork for the formation of such events rather than preventing them. According to the participants, one of the most important obstacles to preventing vandalism in the region is the confusion of authority due to the fact that there are more than one authority in the decision-making mechanism for the protection of cultural values in tourism destinations. Having different institutions in charge for each field makes it difficult to analyze costs and situations. Municipalities and other institutions are working to raise public awareness rather than to repair works.

Prevention of vandalism is quite an important issue for the continuity of the tourism industry. Therefore, it may be useful to conduct qualitative research more frequently and to make preventive recommendations in order to uncover deliberate damage to historic and natural sites at national and international levels. The following recommendations have been developed based on the findings and results of this study.

As a result of the investigations, it was observed that there were no measures to preserve the historic structures around many of the buildings. It is known that protected historical works continue to live longer. Therefore, the places where the historical sites are unprotected should be identified and the necessary measures should be taken. Providing the necessary lighting and increasing the security measures in the tourist areas will contribute to the reduction of vandalism.

The biggest responsibility for the protection of natural structures is on the "Ministry of Culture and Tourism". Although the Ministry has enacted a law on the protection of cultural assets, inadequate enforcement prevents the desired results. Therefore, it should be determined to fulfill the requirements of the existing "Cultural Heritage Protection Law" and to apply deterrent 
penalties. Especially vital for such tourism regions, the Field Management Directorate should be strengthened in the fight against vandalism and should be kept away from any political and interest-based intervention. Especially in places that are declared as protected area, buildings that are constructed illegally over time should be prevented from being overlooked with development plan laws. It would be a deterrent not to allow construction to be carried out next to natural areas, to demolish the structures being built and to apply the necessary sanctions.

Affordable, creative souvenirs can be reproduced to prevent tourists from taking a piece of the historical artifact as a souvenir. In addition, restoration works of the areas exposed to vandalist behavior should be done more effectively. It is important to protect the existing works instead of scraping the area completely or painting it on a dark color.

Similar studies should be carried out in settlements in other provinces and documentation of the damages occurred should be provided. In this way, more attention will be drawn to the issue and awareness will be increased.

\section{References}

Açıkgöz Ş.G. and Ahunbay Z. (2008). 19. Yüzyıl Kayseri Kiliseleri İçin Koruma Önerileri. İTÜ Dergisi, 7(2), 26-37.

Akyol, E. (2006). Kent Mobilyaları Tasarım ve Kullanım Süreci, Yüksek Lisans Tezi, İstanbul Teknik Üniversitesi Fen Bilimleri Enstitüsü, İstanbul.

Allen, V.L andGreenberger, D.B. (1978). Anaesthetic theory of vandalism. Crime Delinquency, 24 (3), 309-321.

Avcı, E., Acar, V. and Aslitürk, G.E. (2016). Kültürel Varlıklar Üzerinde Yapılan Tahribatların Turizm Çerçevesinde Değerlendirilmesi (KuşadasıSelçukÖrneği). Ulakbilge, 4 (8), 171-208.

Bhati, A. and Pearce, P. (2016). Vandalism and tourism settings: An integrative review. Tourism Management, 57, 91-105.

Boz, B. and Beyaztaş, F. (2001). Vandalizm. Sürekli Tıp EğitimiDergisi, 10 (3), 17-18.

Cappadocia Online (2020). Soğanlı vadisi hakkında bilgi. http://www.cappadociaonline.com/soganlitr.html (Date of Access: 01.04.2020)

CBS Philliy. (2014). Vineland, New Jersey. https://philadelphia.cbslocal.com/2014/01/24/2south-jersey-churches-vandalized-overnight/ (Date of Access: 18.03.2020).

Conklın, J.E. (1989). Criminology. NewYork: Macmillan Publishing Company.
ÇevikAladağ, Ş.A. (2011). Kamusal alanda sanat eserinin kalıcılığı ve Mersin Kültür Parkı'nın değerlendirilmesi, Yüksek Lisans Tezi, Mersin Üniversitesi Güzel Sanatlar Enstitüsü, Mersin.

DeMore, S.W., Fisher, J.D. and Baron, R.M. (1988). The Equity-Control Model as a Predictor of Vandalism Among College Students. Journal of Applied Social Psychology, 18 (1), 80-91.

DiCanio, M. (1993). The encyclopedia of violence: Origins, attitudes, consequences. New York: Facts on File.

Doğan, C. (2007). Türkiye Stadyumları Oturma Elemanı Tasarımında Sorunlar ve Bir Çözüm Önerisi, Sanatta Yeterlik Tezi, Mimar Sinan Güzel Sanatlar Üniversitesi Fen Bilimleri Enstitüsü, İstanbul.

Doğan, S. and Demir, İ. (2012). Genel Lise Öğrencilerinin Okul Tahripçiliği Algıları. Ahi Evran Üniversitesi, Eğitim Fakültesi Dergisi, 13 (1), 133-147.

Duneier, M. and Molotch, H. (1999). Talkingcitytrouble: Interactional vandalism, socialinequality, and the urban interaction problem. American Journal of Sociology, 104 (5), 1263-1295.

Eren. D. and Özgüçlü A.K. (2005). TurizmdeVandalizm (Tahripçilik): Nevşehir Örneği. KapadokyaTurizmPaneli, 16 Nisan: Nevşehir.

Erkan, N. Ç. (2005). Yaşam Kalitesini Etkileyen Bir Faktör: Kentsel Vandalizm. İstanbul: TMMOB Şehir Plancıları Odası Yayını.

Fisher, J. and Baron, M. R. (1982). An Equity-Based Model Of Vandalism. Population And Environment, 5 (3), 182-199.

Gladstone, F.J., Sturman, A. and Wilson, S. (1978). Tackling vandalism. HM Stationery Office.

Gunn A.C. and Var T. (2002). TourismPlannig, Basics, Concepts, Cases, (4th Ed.). Newyork: RoutledgeTaylor\&FrancisGroup.

Güleken, Ö.N. and Ünal, Z.G. (2018). Gaziantep Kendirli Kilisesi ve Latin Okulu Koruma ve Restorasyon Önerisi. International Journal Of Social And Humanities Sciences, 2 (1), 83-105.

Haber TS. (2012). SümelaManastırı. https://www.haberts.com/trabzongundemi/sumela-manastiri-duvarlari-utancverici-h6203.html (Date of Access: 10.03.2020).

John Pepitone (2019). Kansas. https://fox4kc.com/news/world-war-i-libertymemorial-vandalized-with-spraypaint/?utm_source=related_1(Date of Access: 18.03.2020

Kvale, S. (1996). InterViews: An introduction to qualitative researcti interviewing. Thousaiid oaks: sage. 
Mayer, G.R., Butterworth, T., Nafpaktitis, M., ve SulzerAzaroff, B. (1983). Preventing school vandalism and improving discipline: A three-year study. Journal of applied behavior analysis, 16(4), 355369.

Moser, G. (1992). What is vandalism? Towards a psychosocial definition and it simplications. Vandalism: Research, Prevention, and SocialPolicy, 20-33.

Namba, R. And Dustin, D. (1992). Towards New Definitions of Depreciative Behavior and Vandalism. Vandalism: Research, Prevention and SocialPolicy, 61-69

Olgun, R. and Yılmaz, R. (2015). Kentsel Yeşil Alanlarda Vandalizm ve Olası Tasarım Çözümleri: Antalya Kenti Örneği. Namı Kemal ÜniversitesiTekirdağ ZiraatFakültesiDergisi, 12 (3), 27-39.

Orhan, H. (2015). Ortaokul 7 ve 8. Sinıf öğrencilerinin okul tahripçiliğine ilişkin algılarının incelenmesi (Adıyaman ili örneği), Yüksek LisansTezi, ZirveÜniversitesi Sosyal Bilimler Enstitüsü, Adıyaman.

Oruç, M. (2008). Yönetici, Öğretmen ve Öğrenci Görüşlerine Göre Ankara İli Genel Lise ve Meslek Lisesi Öğrencilerinin Okul Malına Karşı Gösterdikleri Tahripçi Davranışlar, Yüksek LisansTezi, Ankara Üniversitesi Eğitim Bilimleri Enstitüsü, Ankara.

Patin V. (1999). Will Market Forces Rule?, Unesco The Courier, (July-August), 35-36.

Patton, M. Q. (2002). Qualitative research and evaluation methods (3th ed). Thousand Oaks: Sage Publications.

Sonia Halliday Photo Library (2020). Göreme Açık Hava Müzesi, Yllanlı Kilise. http://www.soniahalliday.com/categoryview3.php?pri=TR72-10-11.jpg (Date of Access: 30.03.2020)

Tarakçı, F.N. (2003). Kentsel Çevrede Vandalizm: Vandalizmin Bank Tasarımına Etkileri, Yüksek LisansTezi, İstanbul Teknik Üniversitesi Fen Bilimleri Enstitüsü, Istanbul.

Tarcan, S. (2007). İlköğretim Okullarında Ders Sırasında Öğrenciler Arasında Görülen Vandalist Davranışlar, Yüksek Lisans Tezi, Mersin Üniversitesi Sosyal Bilimler Enstitüsü, Mersin.

TC Erciş Kaymakamlığı.(2019) Urartu Yazıtları .http://www.ercis.gov.tr/urartu-yazitlari (Date of Access: 15.02.2020)

The Local It. (2019). ItalyaColoseum. https://www.thelocal.it/20190430/tourist-caughtvandalising-colosseum-in-rome (Date of Access: 18.02.2020)
Tripadvisor (2019). Çavuşinde Bulunan Vaftizci Yahya Kilisesi hakkında bilgi. https://th.tripadvisor.com/LocationPhotoDirectLi nk-g2187725-d3547826-i237435407Church_Of_St_John_The_Baptist_Vaftizci_Yahy a_Kilisesi-Cavusin_Cappadoci.html (Date of Access: 01.04.2020)

Tulsa World. (2019). Oklahoma. https://www.tulsaworld.com/opinion/editorials/tu lsa-world-editorial-bigoted-vandalism-must-notrepresent-oklahoma/article_dd330e11-cce2-5f0aa16f-6de53f945117.html (Date of Access: 18.03.2020)

Tutar, F., Kocabay, M. and Kılınç, N. (2007). Turizmsektöründe e-ticaretuygulamaları: Nevşehir örneği. SelçukÜniversitesiKaraman İİBF Dergisi 9(12), 196-206.

Türkiye Turizm (2019). Peribacaları'na skandal otel inşaatına kim izin verdi? Peribacaları'na skandal otel inşaatına kim izin verdi? adlı gazete haberi. https://www.turkiyeturizm.com/peribacalarinaskandal-otel-insaatina-kim-izin-verdi57733h.htm ((Date of Access: 20.03.2020).

Türkoğlu, G. (1991). Vandalizmve Kent Mobilyası. Kamu Mekanları Tasarımı Kent Mobilyaları Sempozyumu IMSÜ Mimarlı Fakültesi Yayınları.

Ünişen, A. and Demirbağ, B. (2016). Ortaokul Öğrencilerinde Vandalizmin Aile İlişkileri ve Bazı Değişkenler Açısından İncelenmesi (Adıyaman İli Örneği). Education Sciences, 11(2), 49-60.

Van Vliet, W. (1984). Vandalism: An Assessment and Agenda, Vandalism: Behaviour and Motivations (Edt: C.L. Leboyer), New York: Elsevier Science Publishing

Yavuz, Y. (2018). Urartu Yazitları. http://www.turizmhaberleri.com/haberayrinti.as p?ID=33814 (Date of Access: 30.02.2020)

Yener, Ö.,Gülaçtı, F. and Çıkılı, Y. (2004). Saldırganlığın Psikolojik- Kültürel Boyutu ve Vandalizm. Doğu Anadolu BölgesiAraştırmaları, 144-149.

Ylldırım, A. (2017). Investigating the frequency, causes and results of school vandalism according to the views of secondary students and teachers, Master Thesis, Yıldırım Beyazıt Üniversitesi, SosyalBilimlerEnstitüsü, Ankara.

Yıldırım, A. (1999). Nitel araştırma yöntemlerinin temel özellikleri ve eğitim araştırmalarındaki yeri ve önemi, Eğitim ve BilimDergisi, Cilt 23, Sayı 112, $7-17$

Yıldırım, A. and Şimşek, H. (2008). Sosyal Bilimlerde Nitel Araştırma Yöntemleri, Ankara: Seçkin Yayınları 